\title{
Origin of rare bovine rotavirus strains detected from Japanese children
}

\author{
Kei Numazaki* \\ Division of International Infectious Diseases, Graduate School of Health and Welfare, International University of Health and Welfare, Japan
}

Rotavirus (RV) is an important viral pathogen causing acute gastroenteritis (AGE) in humans. As most of infants have received the rotavirus vaccine rotavirus infections among infants and young children has since decreased significantly in developed countries [1]. Each year, the vaccine prevents an estimated 40,000 to 50,000 hospitalizations among U.S. infants and young children [2]. RV infects not only humans but also various young domestic and wild animals, such as monkeys, bovine, pigs, horses, dogs, cats, rats, chicken and deer [3-6]. Although nature of RV in spans of many mammals and birds, infection of RV infection in humans is virtually limited to humans. Reports of the epidemic strain in local areas are very important to investigate the pandemic from the epidemic in the region.

$\mathrm{RV}$, a member of the family Reoviridae, has 11 segments of doublestranded RNA as a genome, and the viral particle is composed of the outer capsid, inner capsid and core [7]. In some group of RV the outer capsid consists of two structural proteins, VP4 and VP7, which contain neutralization antigens. The inner capsid consists of structural protein VP6. Based on the antigenicity of the inner capsid protein VP6 and genomic characteristics, RV is classified into seven groups (A-G), among which group A RV is the major etiologic agent in humans and animals. For epidemiological investigations of RV, a genetic classification system based on the outer capsid proteins VP7 (G type) and VP4 (P type) has been adopted [8].

While at least $12 \mathrm{G}$ genotypes have been isolated from humans, G1, G2, G3, G4, and emerging G9 are major genotypes of human rotaviruses [3]. Several $\mathrm{P}$ genotypes $(\mathrm{P}[1]-[3], \mathrm{P}[5], \mathrm{P}[7], \mathrm{P}[9]-[11]$, $\mathrm{P}[14], \mathrm{P}[19]$, and $\mathrm{P}[25]$ ) have been detected sporadically in the human population [9-11]. As human $\mathrm{P}$ genotypes, $\mathrm{P}[8]$ is the most common genotype worldwide, followed by $\mathrm{P}[4]$ and $\mathrm{P}[6]$. Also, 6 nonstructural proteins (NSP) are known [3]. In human RVs, five common $\mathrm{G}$ and $\mathrm{P}$ genotype combinations (genogroups) have been identified: G1P[8], G2P [4], G3P [8], G4P[8], and G9P [8] on the Wa-like genome constellation (I1-R1-C1-M1-A1-N1-T1-E1-H1), and G2P[4] on the DS-1-like constellation (I2-R2-C2-M2-A2-N2-T2-E2-H2) . AU-1-like rotaviruses make up a third group of human $\mathrm{RV}$, which is distributed at low prevalence and has a distinct gene constellation (G3-P[9]-I3-R3C3-M3-A3-N3-T3-E3-H3) .

Although G6 human rotavirus is quite rare, it is the major type among RVs from cattle. In a study of Japanese cows, $59.1 \%$ of isolates belonged to G6. The first G6P[9] strain, PA151, was isolated from an Italian child with AGE [12], followed by the Se584 strain from the United States [13], several Hungarian strains [14]. G6P[9] has subsequently been reported in Japan [15-17], Australia [18], and Tunisia [19]. Usually, bovine G6 strains were combined with P[5], P[1] and others worldwide [20].
Recently, full-genome sequences of RV strains have been increasingly analyzed in order to understand the interspecies transmission, reassortment, and evolutionary relationships between human and animal RVs. In the previous study $[15,16]$, nearly full-length sequences of all the gene segments were determined to investigate the genetic origin of the unique human G6P[9] RVs detected in Japan. The authors [21] considered that their isolates represented reassortment events between bovine-like human rotaviruses and human/feline AU1-like rotaviruses. G6 is a common genotype in cattle/buffalo [22], sheep [23], and goats [24,25] and has been identified sporadically or at a low prevalence in rabbits and pigs [26]. G6P [14] in Egypt [27] and G6P [9] in Burkina Faso [28] in either was reported as a rare virus. The patient from whom the unique human G6P[9] RVs detected recently in Japan did not have previous contact with obvious bovine or other sources of infection.

All other genes of the detected strain except for the NSP3 were relatively closely related to at least one of the human G6 RVs reported in Europe and the U.S. In a study from Miyagi Prefecture of Japan G6P [9] (M72S11) per sample was found from a 2-year-old toddler in 2011 [29]. Also G6P [9] have been detected from more than 3 cats of Mie Prefecture of Japan. These findings suggest that human G6 RV which had occurred by reassortment between human and feline or bovine $\mathrm{RV}$ are distributed worldwide, despite low prevalence. Since genotypes of a few gene segments are different among those human G6 strains, this suggests that G6 rotaviruses may occur independently in various locations or countries through reassortment among local strains.

Although infections with feline rotaviruses (FRVs) rarely cause severe illness in cats [30,31], FRVs have captured attention as perpetuating, albeit infrequent, sources of human disease. Human RV with genetic homology to FRV had been isolated from widespread geographical locations, including Japan [32,33], Israel [34], Tunisia, and United States [35]. Additionally, putative human/feline reassortant rotaviruses have been identified in children in Italy [36].

Two $\mathrm{G}$ and $\mathrm{P}$ genotypes identified combinations carried by rotaviruses circulating in the cat population were G3P[9] and G6P[9].

Correspondence to: Kei Numazaki, Division of International Infectious Diseases, Graduate School Departments of Pediatrics and Infection Control, University Hospital, International University of Health and Welfare, 537-3 Iguchi, Nasushiobara, Tochigi, 329-2763, Japan, Tel: +81-287-39-3060, Fax: +81-287-393001, E-mail: numazaki@iuhw.ac.jp

Key words: rotavirus gastroenteritis, endemic strain, genotype, G6P [9], bovine rotavirus, reassortment

Received: March 05, 2018; Accepted: March 25, 2018; Published: March 29, 2018 
Both G3P[9] and G6P[9] genotypes have been isolated from humans. $\mathrm{G} 3 \mathrm{P}[9]$ is a recognized feline genotype (AU-1-like and BA222-like genotype constellations [37]. Ferine RV (G6P[9] and G3P[9]) were detected at a low prevalence (3.0\%) in the cat population in the United Kingdom. G6 was the more prevalent genotype (84\%) and was detected in Scotland, the Midlands, and Cornwall, which are geographically distinct regions encompassing the length of the United Kingdom [37]. This is similar to estimates from other countries including Japan but showed regional and seasonal variations. Longitudinal sampling strategies based on this prevalence could be used to investigate transmission dynamics in more detail. The absence of an association between RV infection and diarrhea in cats is in stark contrast to humans.

Infection has also been associated with diarrhea and decreased productivity in cows [38], suckling pigs, and horses. Asymptomatic infections are reported, although their importance in transmission is not well understood due to the lack of population-based studies [39]. In cows, asymptomatic individuals shed similar viral titers to those of clinically infected individuals, and the roles of virulent and avirulent strains of RV have been postulated [40]. Asymptomatic infection may be a reflection of the nature of the relationship of G6P[9] and G3P[9] with the feline host [41].

The possibility of G6 feline origin at some historical point has been proposed. With clustering of published human G6 genotypes with our feline G6 genotypes, rather than with published bovine G6 genotypes [42], it was strongly suggests that G6P[9] genotypes were examples of zoonotic or anthropo-zoonotic transmission between cats and humans.

G6P[9] is a relatively common feline rotavirus exists at low prevalence in cat population in Japan. Transmission events between both cats or bovine and human likely existing, although they are infrequent and do not cause outbreaks of disease. The surveillance of $\mathrm{RV}$ in domestic pet population is important for investigating rotavirus genetic diversity, elucidating the role of asymptomatic carriage, exploring zoonotic risk, and monitoring the potential role of nonhuman rotaviruses in the evolution of RV.

\section{Conflict of interest}

No commercial relationship or potential conflict of interest related to the submission of this manuscript.

\section{References}

1. Steele AD, Cunliffe N, Tumbo J, Madhi SA, De Vos B, et al. (2009) A Review of rotavirus infection in and vaccination of human immunodeficiency virus-infected children. J Infect Dis 200 (Suppl 1): S57-62. [Crossref]

2. Numazaki K (2016) Characteristics of rotavirus infections before and after introduction of rotavirus vaccines in Japan. Aperito J Infect Dis Vaccines 2: 1-15.

3. Estes MK, Greenberg HB (2013) Rotaviruses. In: Fields BN, Knipe DM, Howley PM (Eds.) Fields virology. Lippincott, Williams \& Wilkins, Philadelphia, 1347-1401.

4. Ghosh S, Kobayashi N (2014) Exotic rotaviruses in animals and rotaviruses in exotic animals. Virusdisease 25: 158-172. [Crossref]

5. Santos N, Hoshino Y (2005) Global distribution of rotavirus serotypes/genotypes and its implication for the development and implementation of an effective rotavirus vaccine. Rev Med Virol 15: 29-56. [Crossref]

6. Martella V, Bányai K, Matthijnssens J, Buonavoglia C, Ciarlet M (2010) Zoonotic aspects of rotaviruses. Vet Microbiol 140: 246-255. [Crossref]

7. Gentsch JR, Laird A R, Bielfelt B, Griffin DD, Banyai K, et al. (2005) Serotype diversity and reassortment between human and animal rotavirus strains: implications for rotavirus vaccine programs. J Infect Dis 192(Suppl. 1): S146-S159. [Crossref]

8. Matthijnssens J, Ciarlet M, McDonald SM, Attoui H, Bányai K, et al. (2011) Uniformity of rotavirus strain nomenclature proposed by the Rotavirus Classification Working Group (RCWG). Arch Virol 156(8): 1397-1413. [Crossref]
9. Mandal P, Mullick S, Nayak MK, Mukherjee A, Ganguly N, et al. (2016) Complete genotyping of unusual species A rotavirus G12P[11] and G10P[14] isolates and evidence of frequent in vivo reassortment among the rotaviruses detected in children with diarrhea in Kolkata, India, during 2014. Arch Virol 161: 2773-2785. [Crossref]

10. Steyer A, Naglï̈ T, Jamnikar-CigleneÄki U, Kuhar U (2017) Detection and WholeGenome Analysis of a Zoonotic G8P[14] Rotavirus Strain Isolated from a Child with Diarrhea. Genome Announc 5. [Crossref]

11. Delogu R, Lo Presti A, Ruggeri FM, Cella E, Giovanetti M, et al. (2013) Full-genome characterization of a G8P[8] rotavirus that emerged among children with diarrhea in Croatia in 2006. J Clin Microbiol 51: 1583-1588. [Crossref]

12. Gerna G, Sarasini A, Parea M, Arista S, Miranda P, et al. (1992) Isolation and characterization of two distinct human rotavirus strains with G6 specificity. $J$ Clin Microbiol 30: 9-16. [Crossref]

13. Griffin DD, Nakagomi T, Hoshino Y, Nakagomi O, Kirkwood CD, et al. (2002) Nationa Rotavirus Surveillance System. Characterization of nontypeable rotavirus strains from the United States: identification of a new rotavirus reassortant $(\mathrm{P} 2 \mathrm{~A}[6], \mathrm{G} 12)$ and rare P3[9] strains related to bovine rotaviruses. Virol 294: 256-269. [Crossref]

14. Bányai K, Gentsch JR, Griffin DD, Holmes JL, Glass RI, et al. (2003) Genetic variability among serotype G6 human rotaviruses: identification of a novel lineage isolated in Hungary. J Med Virol 71: 124-134. [Crossref]

15. Yamamoto D, Kawaguchiya M, Ghosh S, Ichikawa M, Numazaki K, et al. (2011) Detection and full genomic analysis of G6P[9] human rotavirus in Japan. Virus Genes 43: 215-223. [Crossref]

16. Numazaki K, Ichikawa M (2014) Clinical and virological characteristics of rotavirus gastroenteritis and prevalence of strains in Tochigi, Japan. In Vivo 28:1141-1147. [Crossref]

17. Cooney MA, Gorrell RJ, Palombo EA (2001) Characterisation and phylogenetic analysis of the VP7 proteins of serotype G6 and G8 human rotaviruses. J Med Microbiol 50: 462-467. [Crossref]

18. Diwakarla S, Clark R, Palombo EA (2002) Expanding distribution of human serotype G6 rotaviruses in Australia. Microbiol Immunol 46: 499-502. [Crossref]

19. Ben Hadj Fredj M, Heylen E, Zeller M, Fodha I, Benhamida-Rebai M, et al. (2013) Feline origin of rotavirus strain, Tunisia, 2008. Emerg Infect Dis 19: 630-634. [Crossref]

20. Jamnikar-Ciglenecki U, Kuhar U, Sturm S, Kirbis A, Racki N, et al. (2016) The first detection and whole genome characterization of the G6P[15] group A rotavirus strain from roe deer. Vet Microbiol 191: 52-59. [Crossref]

21. Numazaki K, Ichikawa M (2017) A study on the origin of bovine rotavirus strains detected from the children of the Nasu district, Tochigi, Japan. Journal of Infectious Diseases and Epidemiology 3: 1-8.

22. Chang KO, Parwani AV, Saif LJ (2000) Comparative sequence analysis of the VP7 genes of G6, G8 and G10 bovine group A rotaviruses and further characterization of G6 subtypes. Arch Virol 145: 725-737. [Crossref]

23. Fitzgerald TA, Munoz M, Wood AR, Snodgrass DR (1995) Serological and genomic characterisation of group A rotaviruses from lambs. Arch Virol 140: 1541-1548. [Crossref]

24. Ghosh S, Alam MM, Ahmed MU, Talukdar RI, Paul SK, et al. (2010) Complete genome constellation of a caprine group A rotavirus strain reveals common evolution with ruminant and human rotavirus strains. J Gen Virol 91: 2367-2373. [Crossref]

25. Pratelli A, Martella V, Tempesta M, Buonavoglia C (1999) Characterization by polymerase chain reaction of ruminant rotaviruses isolated in Italy. Microbiologica 22: 105-109. [Crossref]

26. Gouvea V, Santos N, Timenetsky Mdo C (1994) Identification of bovine and porcine rotavirus G types by PCR. J Clin Microbiol 32: 1338-1340. [Crossref]

27. El Sherif M, Esona MD, Wang Y, Gentsch JR, Jiang B, et al. (2011) Detection of the first G6P[14] human rotavirus strain from a child with diarrhea in Egypt. Infect Genet Evol 11: 1436-1442. [Crossref]

28. Nordgren J, Nitiema LW, Sharma S, Ouermi D, Traore AS, et al. (2012) Emergence of unusual G6P[6] rotaviruses in children, Burkina Faso, 2009-2010. Emerg Infect Dis 18: 589-597. [Crossref]

29. Infectious Agents Surveillance Reports IASR, National Institute of Infectious Diseases (NIID, Japan. Vol. 35 p. 298- 300: 2014. (in Japanese)

30. Hoshino Y, Baldwin CA, Scott FW (1981) Isolation and characterization of feline rotavirus. J Gen Virol 54: 313-323. [Crossref] 
31. Mochizuki M, Nakagomi T, Nakagomi O (1997) Isolation from diarrheal and asymptomatic kittens of three rotavirus strains that belong to the AU-1 genogroup of human rotaviruses. J Clin Microbiol 35: 1272-1275. [Crossref]

32. Nakagomi O, Nakagomi T, Oyamada H, Suto T (1985) Relative frequency of human rotavirus subgroups 1 and 2 in Japanese children with acute gastroenteritis. J Med Virol 17: 29-34. [Crossref]

33. Nakagomi T, Nakagomi O (1989) RNA-RNA hybridization identifies a human rotavirus that is genetically related to feline rotavirus. $J$ Virol 63: 1431-1434. [Crossref]

34. Aboudy Y, Shif I, Zilberstein I, Gotlieb-Stematsky T (1988) Use of polyclonal and monoclonal antibodies and analysis of viral RNA in the detection of unusual group A human rotaviruses. J Med Virol 25: 351-359. [Crossref]

35. Nakagomi T, Nakagomi O (2000) Human rotavirus HCR3 possesses a genomic RNA constellation indistinguishable from that of feline and canine rotaviruses. Arch Virol 145: 2403-2409. [Crossref]

36. De Grazia S, Giammanco GM, Martella V, Ramirez S, Colomba C, et al. (2008) Rare AU-1-like G3P[9] human rotaviruses with a Kun-like NSP4 gene detected in children with diarrhea in Italy. J Clin Microbiol 46: 357-360. [Crossref]
37. Nakagomi O, Ohshima A, Aboudy Y, Shif I, Mochizuki M, et al. (1990) Molecular identification by RNA-RNA hybridization of a human rotavirus that is closely related to rotaviruses of feline and canine origin. J Clin Microbiol 28: 1198-1203. [Crossref]

38. Dhama K, Chauhan RS, Mahendran M, Malik SV (2009) Rotavirus diarrhea in bovines and other domestic animals. Vet Res Commun 33: 1-23. [Crossref]

39. Mukhopadhya I, Sarkar R, Menon VK, Babji S, Paul A, et al. (2013) Rotavirus shedding in symptomatic and asymptomatic children using reverse transcription-quantitative PCR. J Med Virol 85: 1661-1668. [Crossref]

40. Bridger JC, Oldham G (1987) Avirulent rotavirus infections protect calves from disease with and without inducing high levels of neutralizing antibody. J Gen Virol 68: 23112317. [Crossref]

41. German AC, Iturriza-Gómara M, Dove W, Sandrasegaram M, Nakagomi T, et al (2015) Molecular Epidemiology of Rotavirus in Cats in the United Kingdom. J Clin Microbiol 53: 455-464.

42. Kalica AR, Greenberg HB, Wyatt RG, Flores J, Sereno MM, et al. (1981) Genes of human (strain Wa) and bovine (strain UK) rotaviruses that code for neutralization and subgroup antigens. Virology 112: 385-390.

Copyright: @2018 Numazaki K. This is an open-access article distributed under the terms of the Creative Commons Attribution License, which permits unrestricted use, distribution, and reproduction in any medium, provided the original author and source are credited. 